\title{
SCREENING AND OPTIMIZATION OF PECTIN LYASE AND POLYGALACTURONASE ACTIVITY FROM GINSENG PATHOGEN CYLINDROCARPON DESTRUCTANS
}

\section{Gayathri Sathiyaraj, Sathiyaraj Srinivasan, Ho-Bin Kim, Sathiyamoorthy Subramaniyam, Ok Ran Lee, Yeon-Ju Kim, Deok Chun Yang*}

Korean Ginseng Center for Most Valuable Products \& Ginseng Genetic Resource Bank, Kyung Hee University, Suwon 449-701,

Korea.

Submitted: August 30, 2009; Returned to authors for corrections: February 11, 2010; Approved: January 13, 2011.

\begin{abstract}
Cylindrocarpon destructans isolated from ginseng field was found to produce pectinolytic enzymes. A Taguchi's orthogonal array experimental design was applied to optimize the preliminary production of polygalacturonase (PG) and pectin lyase (PL) using submerged culture condition. This method was applied to evaluate the significant parameters for the production of enzymes. The process variables were $\mathrm{pH}$, pectin concentration, incubation time and temperature. Optimization of process parameters resulted in high levels of enzyme (PG and PL) production after ten days of incubation at a $\mathrm{pH}$ of 5.0 at $25^{\circ} \mathrm{C}$ in the presence of $1.5 \%$ pectin. Among different nitrogen sources, urea and peptone showed high production of PG and PL, respectively. The enzyme production and mycelial growth seems to have direct influence on the culture conditions; therefore, at stationary state high enzyme production and mycelial growth were obtained than agitation state. Along with this, optimization of enzyme activity was also determined using various physiological parameters like, temperature, incubation time and $\mathrm{pH}$. Taguchi's data was also analyzed using one step ANOVA statistical method.
\end{abstract}

Key words: $C$. destructans; polygalacturonase; pectin lyases; ginseng

\section{INTRODUCTION}

In plant cells, pectin is a family of complex polysaccharides that contain $\alpha$-1, 4-linked D-galacturonic acid. Pectic substances constitute the main components of the middle lamella that is, the intercellular cement between plant cells where it helps to bind cells together. It also makes up a large portion of a primary cell wall, in which they form an amorphous gel, filling the spaces between the cellulose microfibrils. And also play a major role in cell wall extension and fruit softening (11). Pectic substances are polysaccharides consisting of mostly the chains of galacturonan molecules interspersed with a much smaller number of rhamnose molecules and side chains of galacturonan and some other five carbon sugars. The enzymes that degrade pectic substances are known as pectinases or pectinolytic enzymes. Some chain-

*Corresponding Author. Mailing address: Korean Ginseng Center for Most Valuable Products \& Ginseng Genetic Resource Bank, Kyung Hee University, Suwon 449-701, Korea.; Tel. +82-31-201-2688 Fax +82-31-202-2687.; E-mail: dcyang@khu.ac.kr 
splitting pectinases, called polygalacturonases (PG: EC 3.2.1.15), split the pectin chain by adding a molecule of water and breaking (hydrolyzing) the linkage between two galacturonan molecules; pectin lyases (PL: EC 4.2.2.2), split the chain by removing a molecule of water from the linkage, thereby breaking it and releasing products with an unsaturated double bond. Both the enzymes break the pectin chain at random sites or terminal linkage (exo-pectinases) of the chain and release single unit of galacturonan.

The pectin degrading enzymes have been shown to be involved in the production of many diseases, particularly those characterized by soft-rotting of tissues. Pectin degradation results in liquefaction of the pectic substances that hold plant cells together and in weakening of the cell walls and it leads to tissue maceration. Many phytopathogens produce these enzymes to invade into the plants, including Cylindrocarpon destructans, produce drastic root rot diseases in plants, especially in ginseng. The infection in roots can result in complete decay; hence, the name "disappearing root rot" frequently used to describe this disease (19). Previous research has shown that the fungus Cylindrocarpon destructans (teleomorph Nectria radicicola) is a major root rot pathogen of ginseng $(18,20,21)$.

Ginseng is an important cash crop in various regions of China, Korea, North America and other parts of countries. The ginseng roots are taken orally as adaptogens, aphrodisiacs, nourishing stimulants, and in the treatment of type II diabetes. In recent study, the ginseng proved to have anti-inflammatory effect, as well as it reduces fatigue in cancer patients (13). Hence, serious root rot disease in ginseng caused by $C$. destructans can result in yield losses of up to $25-30 \%(7,23)$.

In this study, the production of pectinolytic enzymes was optimized to determine the severity of pathogenesis. For optimization, various parameters are chosen which will have direct influence on the enzyme production therefore; temperature, $\mathrm{pH}$, incubation period, and substrate concentrations were applied using Taguchi's method of orthogonal array (25). In this array, the columns are mutually orthogonal. That is, for any pair of columns, all combinations of factor levels occur; and they take place an equal number of times.

The preliminary study using Taguchi's method served for the determination of initial levels of the production since no literature information was available on the production from the fungus $C$. destructans and different nitrogen source, sodium chloride concentrations were studied along with this comparative analysis of enzyme production by stationary condition versus agitation condition was also determined.

After uttering PG and PL production, their activities were optimized using various physiological factors, which will escort a complete lesson of the particular enzyme from $C$. destructans.

\section{MATERIALS AND METHOD}

\section{Source of organism and inoculants' preparation}

The fungus used for this study $C$. destructans (KACC 41077) was purchased from KACC (Korean Agriculture of Culture Collection, South Korea) which was isolated from the soil of the ginseng field. The propagation of the culture was maintained on the PDA (Difco) plates. The fungal strain cultured on PDA plates for seven days at $25^{\circ} \mathrm{C}$ was then washed with sterile water to extricate spores. The resulting spore suspension was used as inoculants for the experiments.

\section{Taguchi's orthogonal array}

Taguchi's method has been used to generate enough process information to establish the screening and optimal conditions of parameters for particular process using a minimum number of experiments. The properties of an orthogonal array are such that, between each pair of columns each combination of levels (of variables) appear an equal number of times. Due to orthogonality of the layout, the effects of the other factors will be balanced and give a relative value representing the effects of a level compared with the other 
levels of a given factor. The symbolic designation of these arrays indicates the main information on the size of the experimentation, L16, has 16 trails. The total degree of freedom available in an orthogonal array is equal to the number of trails minus one. In this study four columns are designed with different factors as shown in Table 1. Each of these factors assigned with four levels, therefore, 1, 2, 3 and 4 levels respectively. Table 2 shows the experimental condition designed using L16 orthogonal array system. All the parameters were conducted using Czapek Dox mineral medium supplemented with apple pectin (Sigma, South Korea) containing $1 \mathrm{~g} \mathrm{KH}_{2} \mathrm{PO}_{4}, 2 \mathrm{~g} \mathrm{NaNO}_{3}, 0.50 \mathrm{~g} \mathrm{MgSO}_{4} .7 \mathrm{H}_{2} \mathrm{O}, 0.05$ g KCl, $0.01 \mathrm{~g} \mathrm{FeSO}_{4}$, in 1 L.dH $\mathrm{H}_{2} \mathrm{O}$ and incubated at appropriate temperatures without agitation. Based on the experimental days the liquid cultures were filtered through Whatman No.1 filter paper and centrifuged at $5000 \mathrm{~g}$ for 20 min. The protein concentration was assayed using Bradford's method. The supernatant was stored at $-20^{\circ} \mathrm{C}$.

Table 1. Taguchi's experimental design matrix and production of pectinolytic enzymes by $C$. destructans

Levels

Trail No. pH Incubation time Pectin Temperature

\begin{tabular}{lllll}
\hline 1 & 1 & 1 & 1 & 1 \\
2 & 1 & 2 & 2 & 2 \\
3 & 1 & 3 & 3 & 3 \\
4 & 1 & 4 & 4 & 4 \\
5 & 2 & 1 & 2 & 3 \\
6 & 2 & 2 & 1 & 4 \\
7 & 2 & 3 & 4 & 1 \\
8 & 2 & 4 & 3 & 2 \\
9 & 3 & 1 & 3 & 4 \\
10 & 3 & 2 & 4 & 3 \\
11 & 3 & 3 & 1 & 2 \\
12 & 3 & 4 & 2 & 1 \\
13 & 4 & 1 & 4 & 2 \\
14 & 4 & 2 & 3 & 1 \\
15 & 4 & 3 & 2 & 4 \\
16 & 4 & 4 & 1 & 3 \\
\hline
\end{tabular}

Table 2. Variables (factors) and their levels used in Taguchi's method

\begin{tabular}{lcccc}
\hline \multirow{2}{*}{ Factors } & \multicolumn{4}{c}{ Levels } \\
\cline { 2 - 5 } & 1 & 2 & 3 & 4 \\
\hline $\mathrm{pH}$ & 4.5 & 5.0 & 6.0 & 7.0 \\
Incubation time (days) & 2.0 & 6.0 & 8.0 & 10.0 \\
Pectin concentration $(\%)$ & 7.5 & 1.0 & 1.3 & 1.8 \\
Temperature $\left({ }^{\circ} \mathrm{C}\right)$ & 23.0 & 25.0 & 28.0 & 30.0 \\
\hline
\end{tabular}

\section{Analysis of Taguchi's experiment}

Once the experimental design has been determined and the trails have been carried out, the measured performance characteristic from each trail can be used to analyze the relative effect of the different parameters. To determine the effect of each variable has on the output, the signal-to-noise ratio, or the SN number, needs to be calculated for each experiment conducted. The calculation of the $\mathrm{SN}$ for the first experiment in the array above is shown below in the equations (1) below,

$$
\mathrm{S} / \mathrm{N}(\mathrm{dB})=-10 \log \sum_{i=1}^{n} y_{i}^{2} / \mathrm{n}=-10 \log \left(y^{2}+\mathrm{s}^{2}\right)
$$

After calculating the $\mathrm{SN}$ ratio for each experiment, the average $\mathrm{SN}$ value is calculated for each factors and level.

Once these $\mathrm{SN}$ ratio values are calculated for each factor and the range $\mathrm{R}(\mathrm{R}=$ high $\mathrm{SN}$ - low $\mathrm{SN})$ of the $\mathrm{SN}$ for each parameter is calculated and entered. The larger the $\mathrm{R}$ values for a parameter, the larger the effect of the variable as on the process. This is because the same change in signal causes a larger effect on the output variable being measured.

The effect of this factor is then calculated (2) by determining the range:

$$
\Delta=\text { Maximum }- \text { Minimum }
$$

Apparently deposition rate has the largest effect on the processor yields and that temperature has the smallest effect on the processor yield. 
Optimization of enzyme production using nitrogen source / $\mathrm{NaCl}$ concentration / Agitation and stationary culture condition

The enzyme productions were further optimized using new parameters designed by captivating the best trail parameter from the Taguchi's method. The effect of nitrogen sources and sodium chloride concentrations were checked to determine the best nitrogen source and influence of sodium chloride in the production of enzyme. The fungus was grown on the different nitrogen sources such as, urea, yeast extract, beef extract, peptone, $\mathrm{KNO}_{3}$ and $\mathrm{NaNO}_{3}$ at the concentration of $0.5 \%$ level. The consequence of sodium chloride on enzyme production by $C$. destructans was carried out by incorporating $\mathrm{NaCl}$ at a range of $0-2.5 \%$ into the culture medium. Besides with the enzyme production, mycelial dry weight was also determined. The culture broth was filtered through the pre-weight Whatman No.1 filter paper, followed by drying to constant weight at $40^{\circ} \mathrm{C}$ for about $24 \mathrm{~h}$. The final biomass was expressed as dry cell weight $(\mathrm{g} / \mathrm{ml})$. Growth rate (biomass) of fungus was also estimated between the agitated culture $\left(180 \mathrm{rpm}\right.$ at $\left.25^{\circ} \mathrm{C}\right)$ and the stationary culture (incubated at $25^{\circ} \mathrm{C}$ ) using the standard mycelia dry-weight method, in addition to, enzyme activity was also checked.

\section{Optimization of enzyme activity}

The polygalacturonase and pectin lyase activities were carried out using different parameters as follow:

Incubation time: The effect of time on enzyme activity was determined by incubating the reaction mixture up to the appropriate times, i.e., 10-120 $\mathrm{min}$.

pH: The impact of pH on enzyme activity was studied by adjusting the $\mathrm{pH}$ to acquire desired ranges from 3.5-8.5 using 1 $\mathrm{N} \mathrm{NaOH}$ and $1 \mathrm{~N}$ acetic acid.

Temperature: The enzyme reaction was carried out in different temperatures at $25,30,37,40$, and $70^{\circ} \mathrm{C}$, the maximum activity was checked.

\section{Protein determination}

Protein content of the culture filtrates were determined by
Bradford's method using BioRad reagent and bovine serum albumin (BSA) as standard (6).

\section{Enzyme assay}

Polygalacturonase activity was checked by quantifying end groups released during the reaction and it was assayed using the procedure of Panda et al. (15). The amount of substrate (polygalacturonic acid) and enzymes were 0.4 and $0.086 \mathrm{ml}$ dissolved in $0.05 \mathrm{M}$ sodium acetate buffer ( $\mathrm{pH} 5.2$ ), respectively. The reaction carried out by incubating at $37^{\circ} \mathrm{C}$. One unit of enzyme activity was the amount of enzyme catalyses the release of $1 \mu \mathrm{mol}$ of galacturonic acid per unit volume of culture filtrate per unit time at standard assay conditions. Galacturonic acid (Sigma) was used as standard for calibration of enzyme activity. The calculated eq. (3)

$\operatorname{Activity}\left(\frac{U}{m L}\right)=\left(\frac{m g \circ f \text { galacturonic acid }}{212.12}\right)\left(\frac{1}{20}\right)\left(\frac{1}{0.086}\right)$

Pectin lyase activity was determined spectrophotometrically by the procedure described in Alana et al. and Albersheim $(1,3)$. The reaction mixture $(1.25 \mathrm{ml})$ contained $0.1 \mathrm{~mol} / \mathrm{l}$ citrate phosphate buffer ( $\mathrm{pH} 6.0$ ), $0.5 \%$ (w/v) citrus pectin (D.E.), and the appropriate volume of crude enzyme extract (final concentration $1 \mathrm{pg}$ of protein per $\mathrm{ml}$ ). This mixture, without substrate, was pre-incubated at $40^{\circ} \mathrm{C}$ for $15 \mathrm{~min}$ and the reaction initiated with the addition of the substrate and again incubated for $60 \mathrm{~min}$. Enzyme inactivated by boiling for $3 \mathrm{~min}$ was used as a control. One unit of activity is the amount of enzyme which produces an increase of 1 unit of $\mathrm{A}_{235}$, per min.

\section{RESULT}

\section{Taguchi's experiment result analysis}

Cylindrocarpon destructans are phytopathogenic fungus causing rot diseases in plants especially rusty rot in ginseng, which leads to yield loss. Submerged fermentation experiments 
study with the designed experimental condition showed significant variation in the polygalacturonase activity and pectin lyase activity from $C$. destructans (Fig. 1). Production levels were found to be highly dependent on the culture conditions. An L16 orthogonal experimental design was used to investigate four different culture components such as, $\mathrm{pH}$, incubation time, amount of pectin as carbon source/inducer and temperature. The experiments were conducted using four levels for each factor. Statistical analysis of the collected data pointed out that the optimal levels of the different factors for polygalacturonase and pectin lyase productions were $\mathrm{pH} 5,10$ days of incubation and $1.5 \%$ pectin and incubation temperature at $25^{\circ} \mathrm{C}$ (Trial 8). The average effect of the factors at the assigned levels on the polygalacturonase production by $C$. destructans was shown in Table 3. This table shows the influence of four individual factors $(\mathrm{pH}$, incubation time, pectin and temperature) on the polygalacturonase and pectin lyase yields. Individually at level stage, $\mathrm{pH}$ has the highest effect in level 4 with $32.012 \mathrm{U} \mathrm{ml}^{-1}$ and whereas pectin as carbon source/inducer, temperature and incubation time show their higher effects in level 3 with $29.7 \mathrm{U} \mathrm{ml}^{-1}$, level 4 with $27.31 \mathrm{U}$ $\mathrm{ml}^{-1}$ and level 4 with $29.7 \mathrm{U} \mathrm{ml}^{-1}$, respectively on the polygalacturonase yield (Table 3). And pectin showed highest effect in level 3 with $30.4 \mathrm{U} \mathrm{ml}^{-1}$ for PL, and whereas incubation time, temperature, and $\mathrm{pH}$ show their higher effects in level 3 with $29.81 \mathrm{U} \mathrm{ml}^{-1}$, level 3 with $26.41 \mathrm{U} \mathrm{ml}^{-1}$ and level 2 with $28.16 \mathrm{U} \mathrm{ml}^{-1}$, respectively on the pectin lyase yield. Culture $\mathrm{pH}$ and pectin concentration is one of the important parameter in fungal cultivation.

The signal -noise ratio were determined to obtain R-value for ranking the factors based on their contribution on the enzyme production. Fig. 2 shows the R- value of each factor that contributes in the enzymes production. In order to conduct an analysis of the relative importance of each factor more systematically, an analysis of variance (ANOVA) was applied to the data. The main objective of ANOVA is to extract from the results how much variations each factor causes relative to the total variation observed in the result. From the results of ANOVA in Table $3 \mathrm{a}$, the $\mathrm{pH}$ and pectin concentration factors had the largest variance for PG and PL, respectively. The variance within the factors and between the factors was analyzed (Table. 3b).

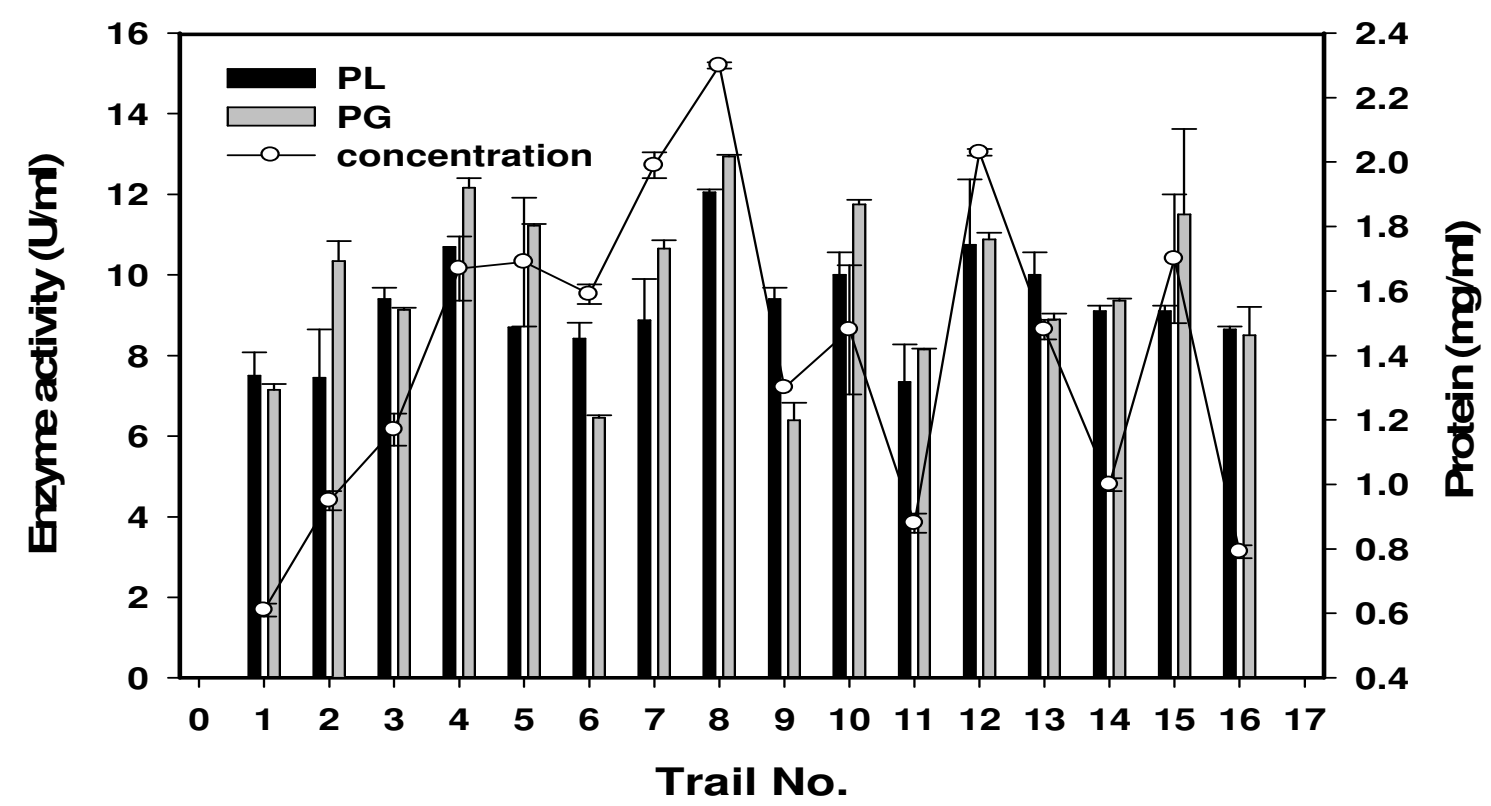

Figure 1. Polygalacturonase and pectin lyase production by $C$. destructans in a submerged culture using Taguchi orthogonal array (Three replicates). 
Table 3a. Analysis of Variance (ANOVA)

\begin{tabular}{lccccccc}
\hline (i) Polygalacturonase & & & & & & & \\
\hline Factors & df & Sum & Mean & Sum sq & SS & Variance & St.dev. \\
\hline $\mathrm{pH}$ & 3 & 98.30 & 24.56 & 2491.01 & 75.15 & 25.05 & 5.00 \\
Incubation time & 3 & 101.20 & 25.30 & 2593.50 & 33.14 & 11.05 & 3.32 \\
pectin & 3 & 98.35 & 24.59 & 2459.37 & 41.18 & 13.72 & 3.70 \\
Temperature & 3 & 97.21 & 24.30 & 2395.58 & 33.14 & 11.05 & 3.32 \\
Errors & 34 & & & & & & \\
Total & 46 & 395.10 & 24.69 & 9939.47 & 184.79 & 12.32 & 3.50 \\
\hline
\end{tabular}

\begin{tabular}{lccccccc}
\hline (ii) Pectin lyase & & & & & & & \\
\hline Factors & df & Sum & Mean & Sum sq & SS & Variance & St.dev. \\
\hline $\mathrm{pH}$ & 3 & 105.44 & 26.36 & 2799.89 & 20.49 & 6.83 & 2.61 \\
Incubation time & 3 & 105.44 & 26.36 & 2827.55 & 48.15 & 16.00 & 4.00 \\
pectin & 3 & 105.43 & 26.35 & 2850.77 & 71.90 & 23.96 & 4.90 \\
Temperature & 3 & 103.66 & 25.915 & 2697.47 & 11.12 & 3.70 & 1.90 \\
Errors & 34 & & & & & & \\
Total & 46 & 419.97 & 26.25 & 11175.67 & 152.25 & 10.15 & 3.20 \\
\hline
\end{tabular}

${ }^{\mathrm{a}}$ Variances and standard deviations are calculated with denominator $=\mathrm{n}-1$.

Table 3b. Summary of ANOVA

\begin{tabular}{lrcrcc}
\hline (i) Polygalacturonase & \multicolumn{1}{c}{} & & \\
\hline Source & SS & df & MS & F-ratio & P-value \\
\hline Between groups & 2.18 & 3 & 0.73 & 0.05 & 0.98 \\
within groups(error) & 182.61 & 12 & 15.22 & & \\
Total & 184.79 & 15 & & & \\
\hline
\end{tabular}

\begin{tabular}{|c|c|c|c|c|c|}
\hline \multicolumn{6}{|l|}{ (ii) Pectin lyase } \\
\hline Source & SS & df & MS & F-ratio & P-value \\
\hline Between groups & 0.59 & 3 & 0.20 & 0.02 & 0.99 \\
\hline within groups(error) & 151.66 & 12 & 12.64 & & \\
\hline Total & 152.25 & 15 & & & \\
\hline
\end{tabular}

*SS, Sums of square; df, degree of freedom; MS, mean squares. 


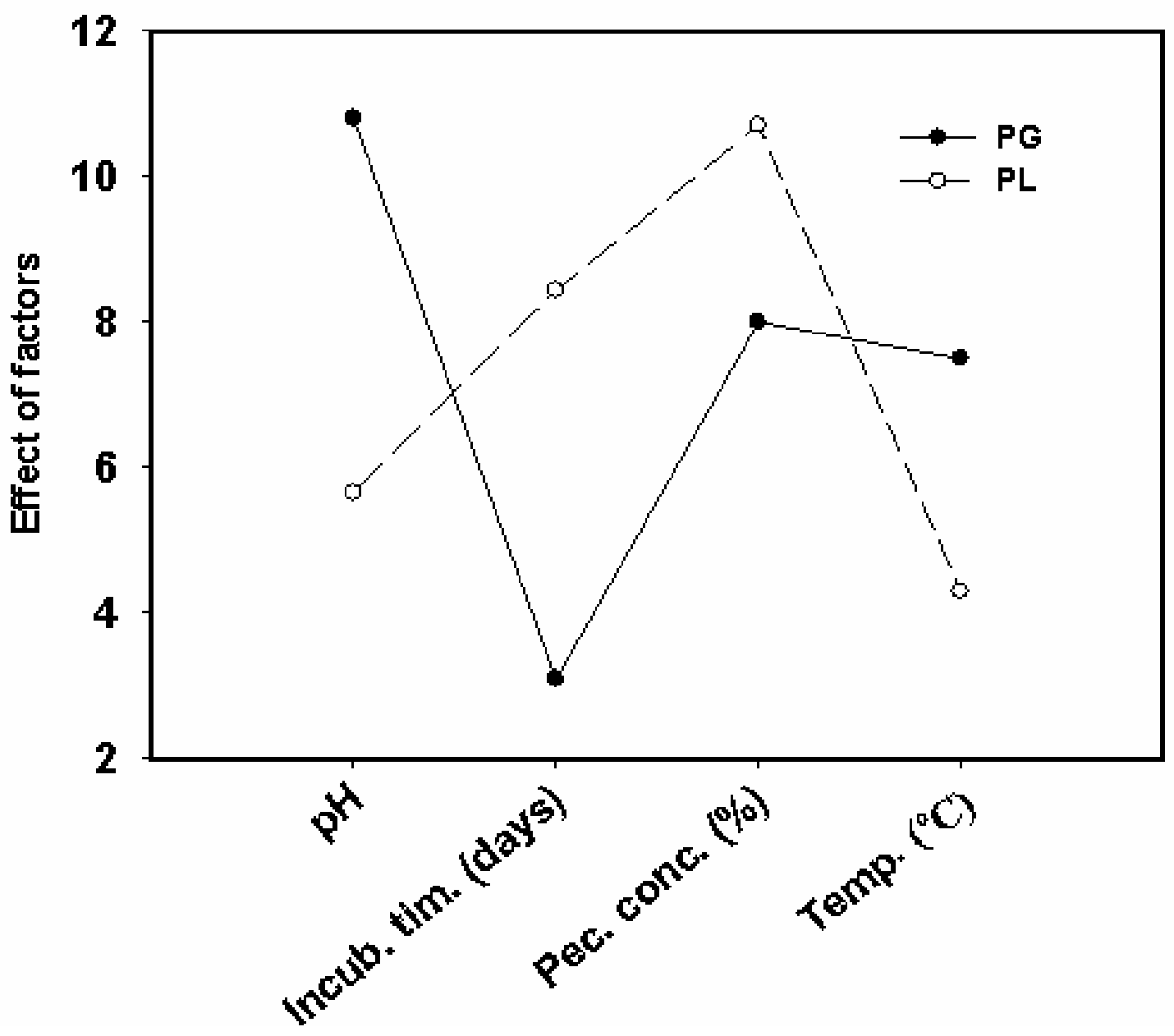

Figure 2. The graphs shows the effect of each factor contribution in the enzyme production.

\section{Effect of nitrogen source / $\mathrm{NaCl}$ concentration / Agitation} and stationary culture condition

Among the various nitrogen source used, urea and peptone gave maximum polygalacturonase activity $\left(12.0 \mathrm{U} \mathrm{ml}^{-1}\right)$ and pectin lyase activity $\left(11.7 \mathrm{U} \mathrm{ml}^{-1}\right)$, from the results, nitrogen source also constitute a profound effect on pectinolytic activity on culture filtrate. Whereas, the biomass weighed high on yeast extract with $3.86 \mathrm{~g}$ dry weight, hence this result confirmed that the yeast extract was only used in the growth, not on the enzyme production (Fig. 3). Sodium chloride was not found to exert a significant role on enzyme production. Even in its absence, considerable activities were found. Fig. 4 shows the
$\mathrm{NaCl}$ effect, in which $0.5 \%$ showed maximum biomass of $3.3 \mathrm{~g}$ (dry weight) as well as paramount PG (13.5 $\left.\mathrm{U} \mathrm{ml}^{-1}\right)$ and PL (12.5 $\mathrm{U} \mathrm{ml}^{-1}$ ) activities. Thereafter, increase in the salt concentration resulted in drastic reduction in enzyme production. The effect of stationary culture influenced the production of both PG $\left(12.0 \mathrm{U} \mathrm{ml}^{-1}\right)$ and PL (11.5 $\left.\mathrm{U} \mathrm{ml}^{-1}\right)$, thus the biomass weighed $3.31 \mathrm{~g}$ (dry weight), and this shows the stationary culture influence the production of pectinolytic enzymes than agitation. Agitation had an inhibitory effect on pectic enzyme production as shown in Table 4 . This could be as a result of catabolite repression by other substances that are enhanced by agitation in the cultures. 


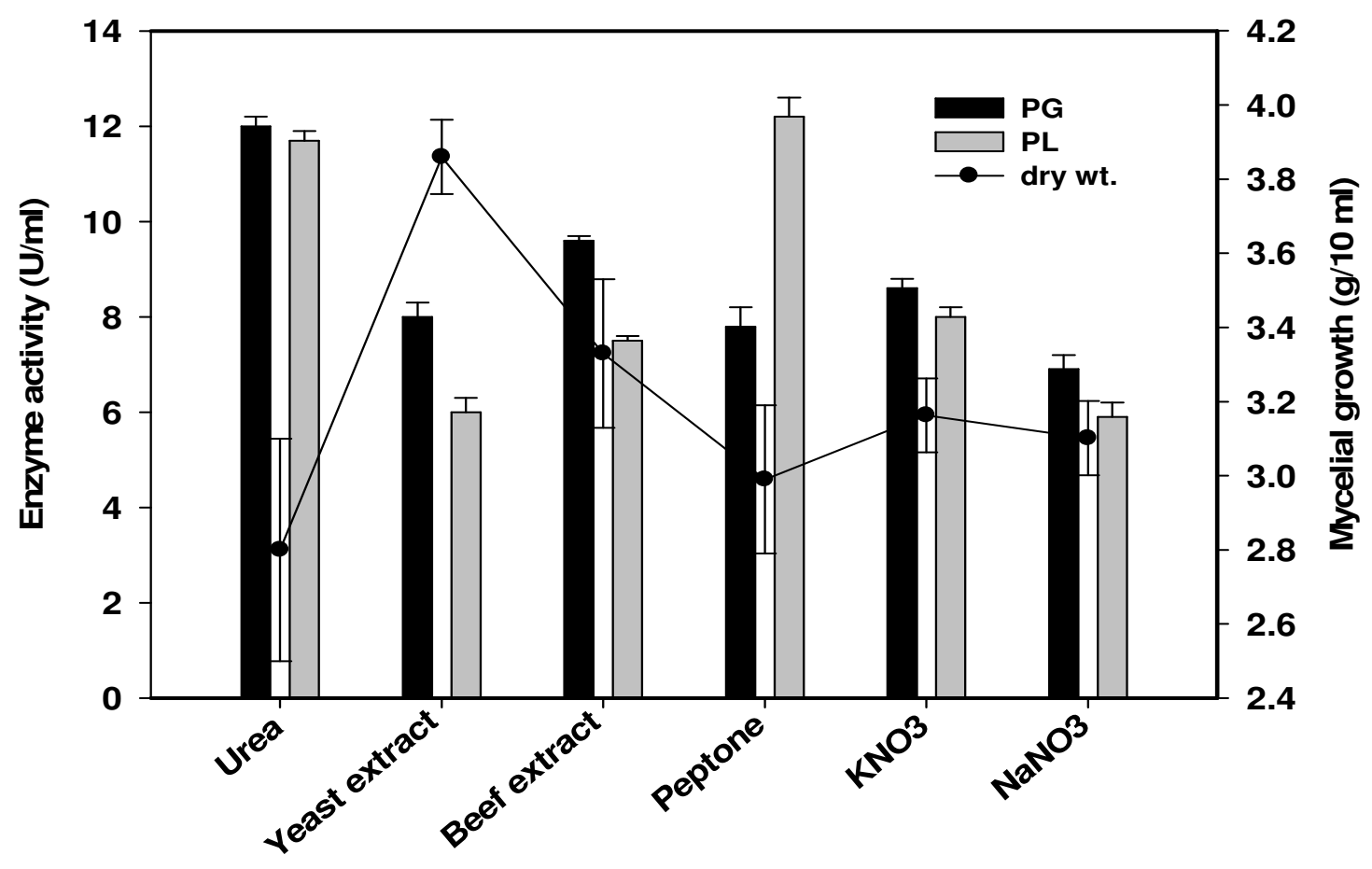

Nitrogen source

Figure 3. Effect of various nitrogen sources $(0.5 \%)$ on enzyme production by $C$. destructans grown in culture medium (pH 5.0 ) containing $1.5 \%$ pectin at $25^{\circ} \mathrm{C}$.

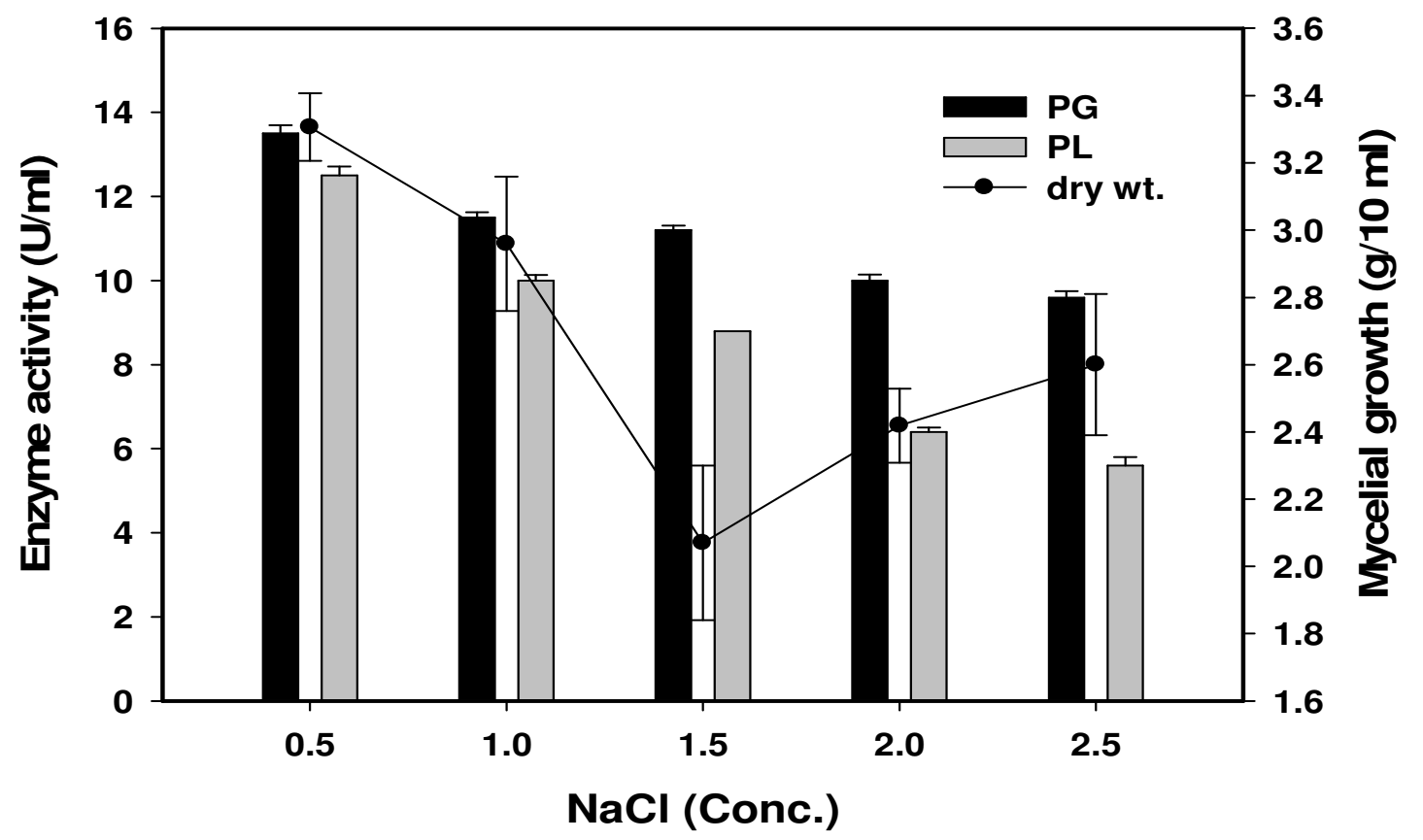

Figure 4. Effect of sodium chloride concentration on enzyme production by $C$. destructans grown in culture medium (pH 5.0) containing $1.5 \%$ pectin at $25^{\circ} \mathrm{C}$. 
Table 4. The effect of agitation and stationary culture technique on growth, PG and PL activity by $C$. destructans cultured for 10 days

\begin{tabular}{lcc}
\hline & Agitation at $\mathbf{2 5}^{\mathbf{C}} \mathbf{C}$ & Stationary at $\mathbf{2 5}^{\mathbf{0}} \mathbf{C}$ \\
\hline Mycelial dry weight $\left(\mathrm{g} 10 \mathrm{ml}^{-1}\right)$ & 0.67 & 3.31 \\
Protein content $\left(\mathrm{mg} \mathrm{ml}^{-1}\right)$ & 0.78 & 1.13 \\
Polygalacturonase activity $\left(\mathrm{U} \mathrm{ml}^{-1}\right)$ & 8.80 & 12.00 \\
Pectin lyase activity $\left(\mathrm{U} \mathrm{ml}^{-1}\right)$ & 6.00 & 11.50 \\
\hline
\end{tabular}

Optimum incubation time, $\mathrm{pH}$ and temperature for pectinolytic activity

The $0.1 \mathrm{U}$ of PG and PL were used to check optimum activity. The incubation time is one of main factor that interprets the enzyme activity; we observed both PG and PL activities elevated at the incubation time of $60 \mathrm{~min}$ and decreased gradually (Fig.5). The optimum $\mathrm{pH}$ for the catalytic reaction was determined from the results shown in Fig. 6. The polygalacturonase and pectin lyase are most begun at $\mathrm{pH} 4.5$ and 5.5 and completely inactivated at $\mathrm{pH}$ values above 6.5 or below 3.2 (result not shown). The result in Fig.7 shows the maximum activity at the temperature of 37 and $30^{\circ} \mathrm{C}$ for polygalacturonase and pectin lyase respectively. Thus it showed the mesophilic nature of the fungi.

The overall result shows maximum pectin lyase and polygalacturonase activity at $30^{\circ} \mathrm{C}$ for $60 \mathrm{~min}$ with the $\mathrm{pH} 5.5$ and $37^{\circ} \mathrm{C}$ for $60 \mathrm{~min}$ with $\mathrm{pH} 4.5$, respectively.

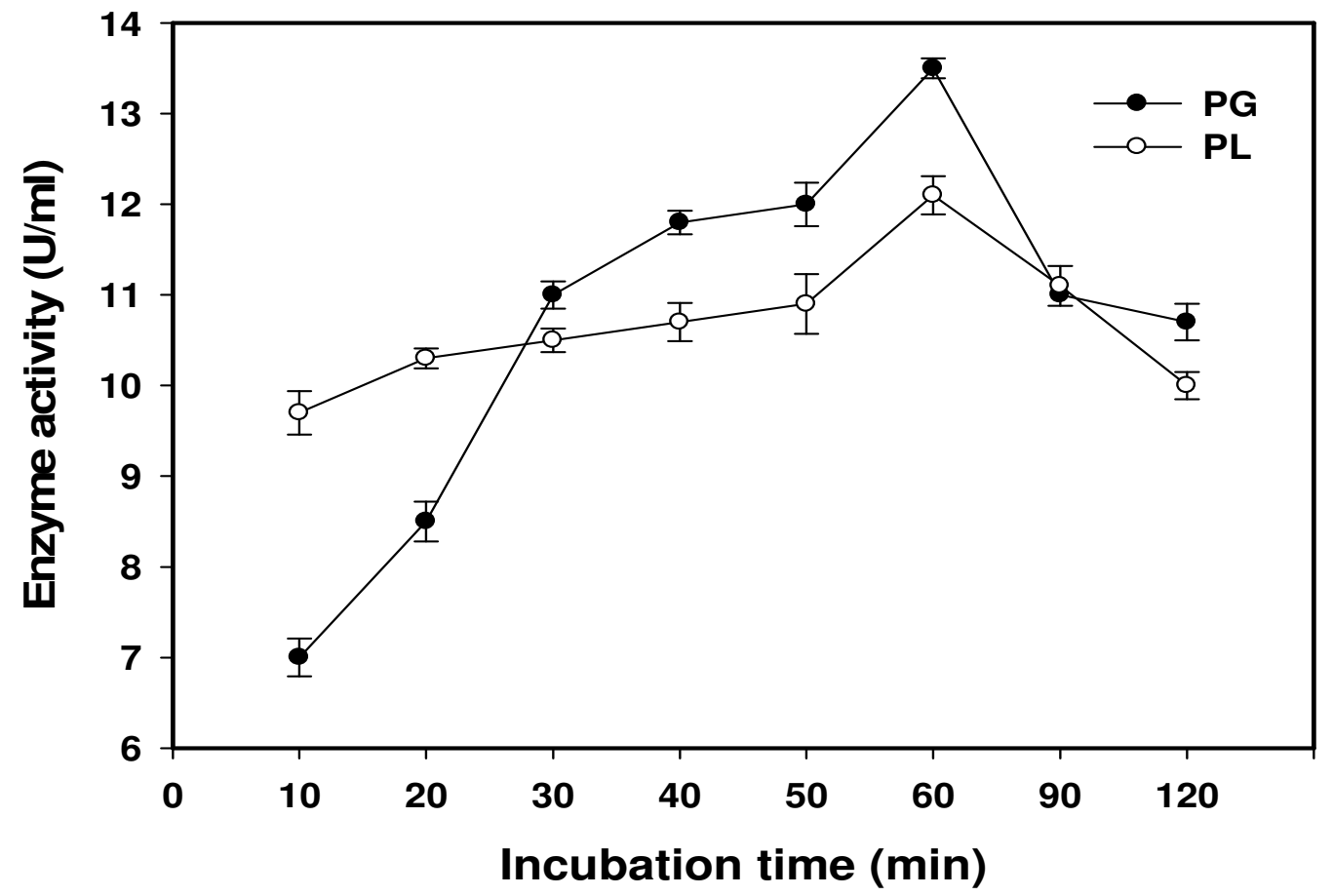

Figure 5. Determining of incubation time for optimum enzyme activity. 


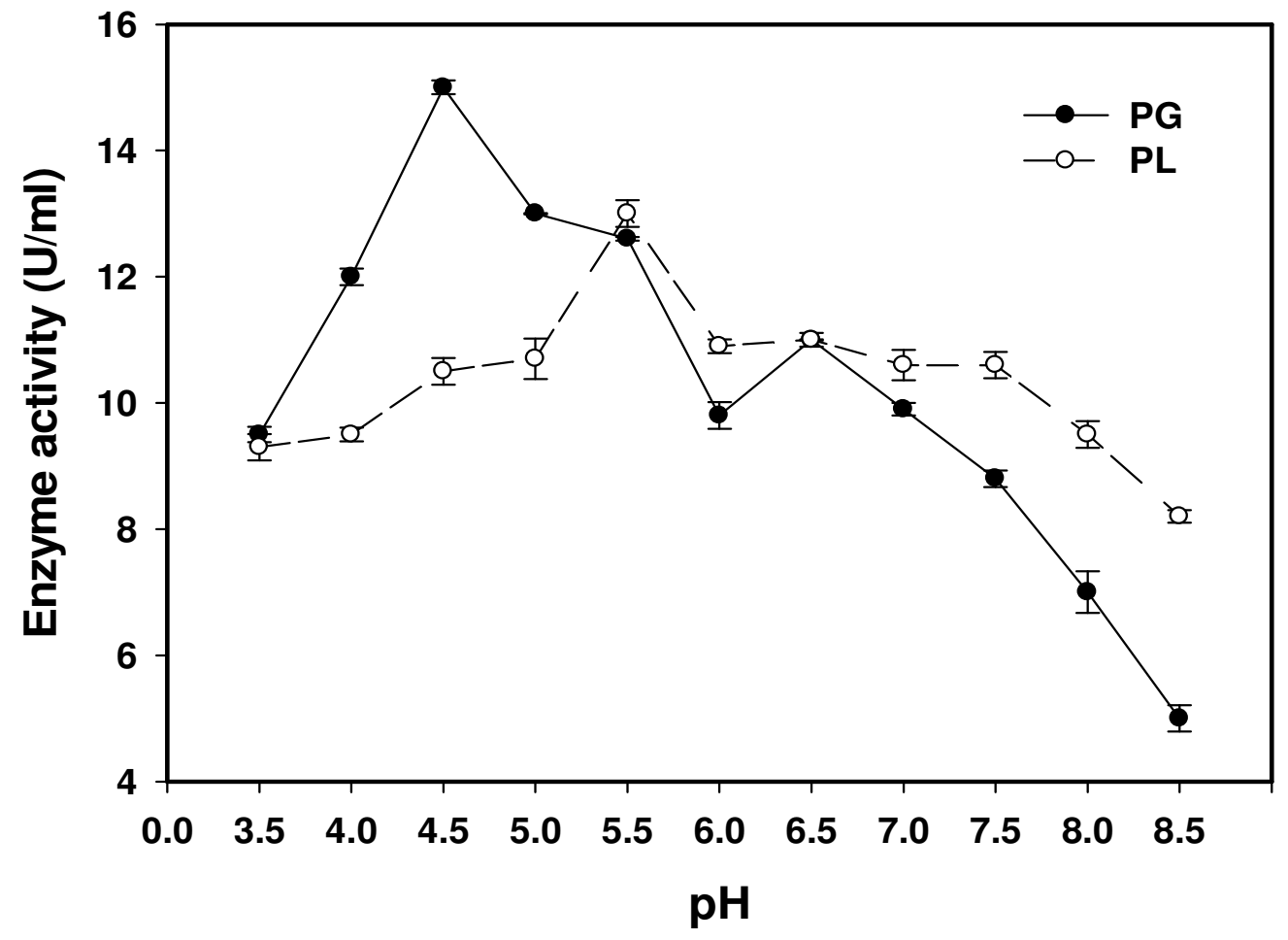

Figure 6. Effect of pH on enzyme activity of polygalacturonase and pectin lyase.

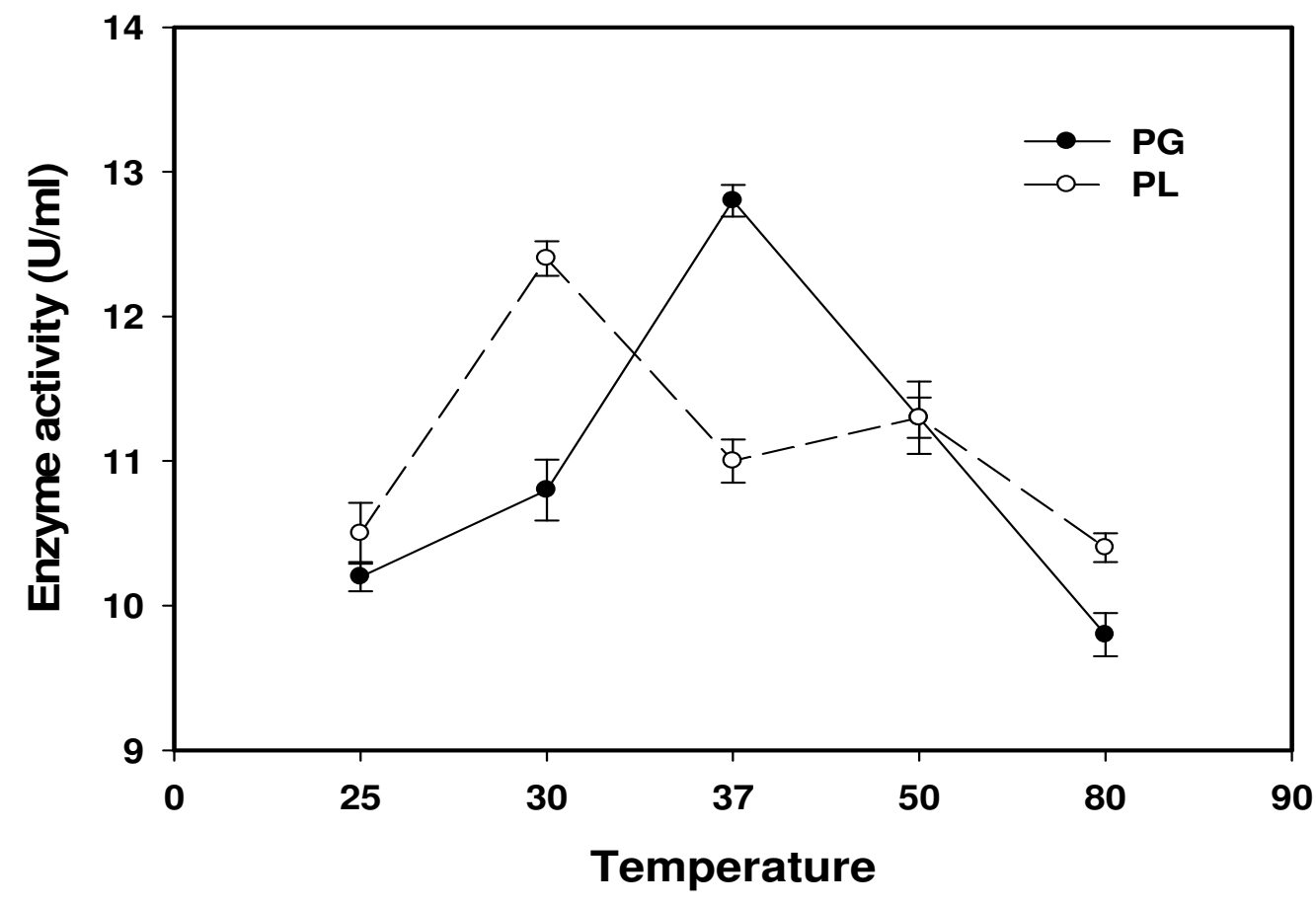

Figure 7. Effect of temperature $\left({ }^{\circ} \mathrm{C}\right)$ on enzyme activity. 


\section{DISCUSSION}

To date, no clear reports are available in literature regarding the optimization conditions for PG and PL enzyme production by $C$. destructans, so we studied preliminary production of these enzymes. From our research, we determined the optimum conditions for the production of pectinolytic enzymes (PG and PL) from $C$. destructans using Taguchi's orthogonal array. The optimum conditions for the production of $\mathrm{PG}$ and $\mathrm{PL}$ was detected in ten days at temperature 25 with $1.5 \%$ pectin in acidic $\mathrm{pH}$ of 5.0. Based on the Taguchi's data calculation, $\mathrm{pH}$ shows more contribution in the production of PG, where as pectin concentration for PL. The Taguchi method reduced research and development costs by improving the efficiency of generating information needed to design systems that are insensitive to usage conditions, manufacturing variation, and deterioration of parts. As a result, development time can be shortened significantly; and important design parameters affecting operation, performance, and cost can be identified. Furthermore, the optimum choice of parameters can result in wider tolerances so that low cost components and production processes can be used. Thus, manufacturing and operations costs can also be greatly reduced.

The nitrogen sources also have an important part in the production of enzymes where urea and peptone showed increased activity of PG and PL, similar data have been reported in Penicillium strain (14) where the non-defined organic urea was found better than the defined nitrogen sources for maximal PG production. $\mathrm{NaCl}$ content neither enhanced nor destroyed the production of enzyme; our investigation also supports the data proved by Mathew et al. (14) in Penicillium sp. It is interesting that although $C$. destructans is not a halophile, still the enzymes were stable in high salt concentrations. The pectinolytic enzyme production was favored by stationary culture condition rather than agitated condition. Dronawat et al. (8) reported an increase in gluconic acid concentration in cultures of $A$. niger with increasing agitation, it could be a reason of less enzyme production.

Optimum $\mathrm{pH}$ for enzyme (PG and PL) activity was observed in the acidic $\mathrm{pH}$; our result gave good agreement with reported data in which, the $\mathrm{pH}$ between 4.0-5.0 was reported to give maximum activity of pectinolytic enzymes in Penicillium italicum (2), Aspergillus niger (9), Fusarium oxysporum and Fusarium equiseti (5). Optimum production of pectic enzymes from many moulds has been reported to be within the acidic $\mathrm{pH}$ range $(24,26)$. The incubation period of $60 \mathrm{~min}$ of reaction time increased the PG and PL activity, at mesophilic (37 and 30) temperature, which proved to be the nature of these enzymes. The same thermolabile nature was also reported in Aspergillus fumigatus by Phutela et al. (17). Many fungal PGs are thermolabile and become irreversibly inactivated by $60^{\circ} \mathrm{C}$ with a few exceptions such as Penicillium (10), Rhizopus (22), and Sclerotinia (4).

Taguchi's approach to guideline design provides the systematic and efficient method for determining near optimum design parameters for performance and cost $(12,16,25)$. Taguchi experimental design involves a study of given system by a set of independent variables (factors) over a specific region of interest (levels) by identifying the influence of individual factors, establishing the relationship among variables and also the performance at the optimum levels. By studying the main effects of each of the factors, the general trends of the influence of the factors towards the process can be predicted and controlled such that a lower or a higher value in a particular influencing factor produces the preferred result. Thus, the levels of factors, to produce the best results can be predicted (Sreenivas Rao et al., 2004; Chang et al., 2006). Any individual factor may interact with the other factors creating the possibility of presence of interactions. This kind of interaction is possible in Taguchi design of experiment. Estimated interaction severity index (SI) of the factors under study helps to know the influence of two individual factors at various levels of the interactions (Han et al., 1998; Venkata 
Dasu et al., 2003; Koo et al., 2006). Furthermore, the conclusions drawn from small scale experiments are valid over the entire experimental region spanned by the control factors and their settings. Therefore, this research will serve as a base line, and it will provide us to work further in detailed study of PG and PL production in this fungus. The purification and the characterization of polygalacturonase from Cylindrocarpon destructans are in process.

\section{ACKNOWLEDGEMENT}

This study was supported by grant from the KGCMVP for Technology Development Program of Agriculture and Forestry, Ministry of Food, Agriculture, Forestry and Fisheries, Republic of Korea.

\section{REFERENCE}

1. Alana, A.; Alkorta, I.; Dominguez, J.B.; Liama, M.J.; Serra J.L. (1990) Pectin lyase activity in a Penicillium italicum strain. Appl. Environ. Microbio. 56, 3755-3759.

2. Alana, A.; Gabilondo, A.; Hernando, F.; Moragues, M.D.; Dominquez, J.B.; Liama, M.J.; Sessa, J.L. (1989). Pectin lyase production by a Penicillium italicum strain. Appl. Environ. Microbiol. 55, 1612-1616.

3. Albersheim, P. (1966). Pectin lyase from fungi. Methods 2 Enzymol. 8, 628-631.

4. Archer, S.W.; Fielding, A. (1975). Thermostable polygalacturonase secreted by Sclerotinia fructigana. J. Food Sci. 40, 423-424.

5. Bahkali, A.H.; AI-Khaliel, A.H.; Elkhider, K.A. (1997). In vitro and In vivo production of pectinolytic enzymes by some phytopathogenic fungi isolated from Southwest Saudi Arabia. Sci. 2, 125-137.

6. Bradford, M.M. (1976). A rapid and sensitive method for the quantitation of microgram quantities of protein utilizing the principle of protein-dye binding. Anal. Biochem. 72, 248-54.

7. Chung, H.S. (1975). Studies on Cylindrocarpon destructans (Zins.) Scholten causing root rot of ginseng. Rep. Tottori. Mycol. Inst. 12, 127 38.

8. Dronawat, S.N.; Svihla, C.K.; Hanley, T.R. (1995) The effects of agitation and aeration on the production of gluconic acid by Aspergillus niger. Appl. Biochem. Biotechnol. 51/152, 347-354.

9. Fawolea, O.B.; Odunfab, S.A. (2003). Some factors an ecting production of pectic enzymes by Aspergillus niger. Int. Biodeterior. Biodegrad. 52, $223-227$.
10. Gillespie, A. M.; Cook, K.; Coughlan, M. P. (1990). Characterization ofendopolygalacturonase produced by solid-state cultures of the aerobic fungus Penicilliuni capsulatum. J. Biotechnol. 13, 279-292.

11. Jacob, N.; Asha Poorna C.; Prema P. (2008). Purification and partial characterization of polygalacturonase from Streptomyces lydicus. Bioresource Technol. 99, 6697-670.

12. Kackar, R.N. (1985). Off-line quality control, parameter design and Taguchi methods, J. Qual Technol. 17, 176-88.

13. Kook, S.; Han, H.K; Kim, G.H.; Choi, K. (2008). The anti-hepatotoxic effect of ginseng in rats: meta-analysis. J. Ginseng Res. 29, 161-170.

14. Mathew, A.; Abi N.E.; Molly, A.G. (2008). Optimization of culture conditions for the production of thermostable polygalacturonase by Penicillium SPC-F 20. J. Ind. Microbiol. Biotechnol. 35, 1001-1005.

15. Panda, T.; Naidu, G.S.N.; Sinha, J. (1999). Multiresponse analysis of microbiological parameters affecting the production of pectolytic enzymes by Aspergillus niger: a statistical view. Process Biochem., 35, 187-95.

16. Phadke, S.M. (1991). Quality Engineering Using Robust Design, Prentice Hall, Englewood Cliffs, N.J., Presented at the Annual Conference of International Society of Parametric Analysts.

17. Phutela, U.; Dhuna, V.; Sandhu, S.; Chadha, B.S. (2005). Pectinase and polygalacturonase production by a thermophilic Aspergillus fumigatus isolated from decomposting organge peels. Braz. J. Microbiol. 36, 6369.

18. Punja, Z.K. (1997). Fungal pathogens of American ginseng (Panax quinquefolius L.) in British Columbia, Canada. Can. J. Plant Pathol. 19, 301-306.

19. Rahman, M.; Punja, Z.K. (2005). Factors influencing development of root rot on ginseng caused by Cylindrocarpon destructans. Phytopathol. 95, 1381-1390.

20. Reeleder, R.D.; Brammal, R.A. (1994). Pathogenicity of Pythium species, Cylindrocarpon destructans, and Rhizoctonia solani to ginseng seedlings in Ontario. Can. J. Plant Pathol. 16, 311-316.

21. Reeleder, R.D.; Roy, R.; Capell, B.B. (1999). Seed and root rots of ginseng (Panax quinquefolius) caused by Cylindrocarpon destructans and Fusarium spp. J. Ginseng Res. 26, 151-158.

22. Ros, J.M.; Saura, D.; Saimeron, M.C.; Lencina, J. (1993). On the response under different treatments of the thermostable endopolygalacturonase produced by Rhizopus nigricans. Z. Lebensm.Unters. Forsch. 1965, 356-359.

23. Seifert, K.A.; McMullen, C.R.; Yee, D; Reeleder, R.D; Dobinson, K.F. (2003). Molecular differentiation and detection of ginseng adapted isolates of the root rot fungus Cylindrocarpon destructans. Phytopathol. 93, 1533-42.

24. Shin, I.; Dowmez, S.; Kilic, O. (1983). Study on pectolytic enzyme 
production from some agricultural wastes by fungi. Chemie Microbiologie Technologie der Lebensm., 8, 87-90.

25. Taguchi, G. (1991). Introduction to Quality Engineering, Asian Productivity Organization (Distributed by American Supplier Institute
Inc., Dearborn, MI). Presented at the Annual Conference of International Society of Parametric Analysts.

26. Zetelaki-Horvath, K. (1980). Factors affecting pectinase activity. Acta Aliment. 10, 371-378.

\section{(cc) Br-ne}

All the content of the journal, except where otherwise noted, is licensed under a Creative Commons License 